\title{
UPAYA PENCEGAHAN DAN PENANGGULANGAN COVID-19 MELALUI PROGRAM KKN MANDIRI GELOMBANG XV TAHUN 2020 UNIVERSITAS SULAWESI BARAT
}

\author{
Septiawan Ardiputra ${ }^{1}$, Muhammad Arafat Abdullah ${ }^{2}$, Laila Qadrini ${ }^{3}$, Nurlaela ${ }^{4}$, Sri Utami Permata ${ }^{5}$, \\ Suburia $^{6}$ \\ ${ }^{1)}$ Prodi Ilmu Politik, FISIP, Universitas Sulawesi Barat, \\ ${ }^{2)}$ Prodi Kehutanan, FAPERTAHUT, Universitas Sulawesi Barat, \\ ${ }^{3)}$ Prodi Statistika, FMIPA, Universitas Sulawesi Barat, \\ 4) Prodi Agribisnis, FAPERTAHUT, Universitas Sulawesi Barat, \\ ${ }^{5,6)}$ Prodi Manajemen, FEKON, Universitas Sulawesi Barat, \\ e-mail : septiawan.ardiputra@unsulbar.ac.id
}

\begin{abstract}
Abstrak
Suatu wabah dinyatakan pandemic artinya WHO memberi alarm pada pemerintah agar semua negara di dunia agar meningkatkan kesiapsiagaan dalam pencegahan dan penanganan wabah. Pandemi Covid-19 merupakan penyakit menular yang disebabkan oleh Virus Corona Virus SARS-COV 2. KKN Mandiri merupakan salah satu bentuk pengabdian kepada masyarakat yang dinisiasi oleh Pusat Pengembangan Kuliah Kerja Nyata (P2KKN) Universitas Sulawesi Barat dengan Tema "Upaya Pencegahan Dan Penanggulangan Covid-19". Berdasarkan observasi lapangan ditemukan berbagai masalah di masyarakat Desa Pallis Kecamatan Balanipa yang menjadi mitra program kegiatan KKN Mandiri seperti ketidaksiplinan dan tidak pahamnya masyarakat dalam penerapan protokol kesehatan, kebiasaan mencuci tangan dengan sabun, tidak memakai masker saat beraktifitas di luar rumah serta tidak terdapat spanduk dan sticker edukasi pencegahan Covid-19. Kondisi tersebut membawa kekhawatiran yang dapat menambah potensi penyebaran dan peningkatan kasus Covid-19. Sehingga kami selaku tim abdimas melakukan upaya pencegahan penularan Covid-19 melalui program kerja KKN Mandiri yang sebelumnya telah disusun terlebih dahulu untuk menjawab permasalahan yang ada di masyarakat. Berikut adalah beberapa dari sekian banyak program kerja yang kami buat dan jalankan seperti Pemberian pemahaman kepada masyarakat tentang penerapan PHBS dengan membiasakan mencuci tangan dengan sabun, memakai masker saat beraktifitas di luar rumah serta pemasangan spanduk dan sticker edukasi pencegahan Covid-19. Beberapa program diatas telah terlaksana dengan baik sesuai dengan schedule yang terdapat pada program kerja dan mendapat antusiasme serta respon positif dari aparat desa serta masyarakat setempat.
\end{abstract}

Kata Kunci : KKN Mandiri, Pencegahan, Penularan, Covid-19

\begin{abstract}
An epidemic is declared a pandemic, which means that WHO is giving an alarm to the government for all countries in the world to increase preparedness in preventing and handling outbreaks. Covid-19 pandemic is an infectious disease caused by the Corona Virus SARS-COV 2. KKN Mandiri is a form of community service initiated by the Pusat Pengembangan Kuliah Kerja Nyata (P2KKN) Universitas Sulawesi Barat with the theme "Upaya Pencegahan Dan Penanggulangan Covid-19". Based on field observations, various problems were found in Desa Pallis Kecamatan Balanipa, who are partners of the Community Service Program activities such as insecurity and lack of understanding of the community in implementing health protocols, the habit of washing hands with soap, not wearing masks when doing activities outside the home and there are no banners and stickers Covid-19 prevention education. This condition brings concerns that can increase the potential for the spread and increase of Covid-19 cases. So that we as the Tim Abdimas make efforts to prevent the transmission of Covid-19 through the KKN Mandiri work program that was previously compiled to answer problems in the community. The following are some of the many work programs that we have created and implemented, such as providing understanding to the public about the implementation of PHBS by getting used to washing hands with soap, wearing masks when doing activities outside the home and installing Covid-19 prevention educational banners and stickers. Some of the programs above have been carried out well according to the schedule contained in the work program and have received enthusiasm and positive responses from village officials and the local community.
\end{abstract}

Keywords : KKN Mandiri, Prevention, Transmission, Covid-19 


\section{PENDAHULUAN}

World Health Organization telah secara resmi menyatakan Covid-19 sebagai pandemic. Menurut WHO, pandemi merupakan terjadinya penyebaran penyakit dengan skala global di seluruh dunia. Suatu wabah dinyatakan pandemic artinya WHO memberi alarm pada pemerintah agar semua negara di dunia agar meningkatkan kesiapsiagaan dalam pencegahan dan penanganan wabah. Pandemi Covid-19 merupakan penyakit menular yang disebabkan oleh Virus Corona Virus SARS-COV 2. Covid-19 telah dinyatakan sebagai pandemi dunia oleh Organisasi Kesehatan Dunia (WHO) dan telah dinyatakan Pemerintah sebagai bencana non alam berupa wabah penyakit yang dalam hal penanganannya diperlukan langkah-langkah penanggulangan terpadu termasuk keterlibatan seluruh komponen masyarakat (K. RI, 2020).

Laporan kasus dan kematian semakin meningkat dan penyakit ini pun dengan cepat menyebar keluar negara China. Organisasi kesehatan Dunia (WHO) pada 31 Januari 2020 menetapkan bahwa Covid-19 sebagai Kedaruratan Kesehatan Masyarakat Yang Meresahkan Dunia atau biasa disebut Public Health Emergency of International Concern (PHEIC) (Nathavitharana et al., 2020). Salah satu upaya dalam pencegahan penyebaran dan penularan Covid-19 adalah tetap menjaga kebersihan diri dan lingkungan (Musafira et al., 2020).

Tanda dan gejala penyakit ini yaitu tergangunya saluran pernafasan seperti batuk, demam dan terjadinya nafas sesak pada penderita. Masa inkubasi terjadi antara 5 sampai 6 hari dengan masa terpanjang sampai 14 hari (Wu et al., 2020). Infeksi terpapar Covid-19 yang berat dapat menyebabkan sindrom pernapasan akut, gagal ginjal, pneumonia bahkan kematian (Gan et al., 2020). Sejak Januari 2020 Elsevier telah membuat pusat sumber daya COVID-19 dengan informasi gratis dalam bahasa Inggris dan Mandarin tentang novel coronavirus COVID-19 (Voss et al., 2020).

Demam disertai kesulitan bernafas dan hasil rontgen menunjukkan infiltrate pneumonia luas di kedua paru merupakan tanda dan gejala klinis yang dilaporkan pada sebagian besar kasus ((2020a), n.d.). Pertanggal 5 Juni 2020 Dirjen pencegahan dan pengendalian Kemkes menyampaikan bahwa di Indonesia lebih dari 30.000 Kasus terkonfirmasi positif covid-19 dengan angka kematian berjumlah 1000 lebih, dimana setiap harinya angka tersebut terus mengalami peningkatan.

Universitas Sulawesi Barat sebagai salah satu Perguruan Tinggi Negeri di Provinsi Sulawesi Barat terpanggil untuk berkontribusi dalam pencegahan dan pananggulangan Covid-19 yang sedang mewabah di masyarakat. Berdasarkan Surat Edaran Rektor Universitas Sulawesi Barat terkait penyelenggaraan Kegiatan Akademik pada Masa Pandemi Covid 19, kegiatan KKN, PKL dan Sejenisnya tetap berjalan secara Mandiri, dimana teknis pelaksanaannya akan diatur oleh LPPM dan Fakultas masing-masing. Melalui Lembaga Penelitian dan Pengabdian Kepada Masyarakat dan Penjaminan Mutu (LPPM dan PM) yang ada di lingkungan Universitas Sulawesi Barat telah merumusukan kegiatan Kuliah Kerja Nyata (KKN) Mandiri di Masa Pandemi Covid-19 dengan Tema Upaya Pencegahan Dan Penanggulangan Covid-19 yang dalam hal ini ditangani langsung oleh Pusat Pengembangan Kuliah Kerja Nyata (P2KKN). Kegiatan KKN merupakan kegiatan terjadwal secara akademik dalam bentuk pengabdian kepada masyarakat yang dilakukan oleh mahasiswa secara interdisipliner, institusional, dan kemitraan sebagai salah satu wujud dari tridharma perguruan tinggi. Dan melalui KKN Mandiri dengan Tema Upaya Pencegahan Dan Penanggulangan Covid-19 yang telah dirumuskan oleh LPPM \& PM merupakan moment yang sangat tepat dalam hal peran serta Civitas Akademika Universitas Sulawesi Barat untuk terjun langsung ke masyarakat untuk melakukan observasi, identifikasi masalah, penyusunan program, pelaksanaan program serta pelaporan hasil kegiatan pengabdian kepada masyarakat dalam bentuk kegiatan KKN Mandiri di masa pandemi Covid-19.

Berdasarkan hasil observasi lapangan ditemukan berbagai masalah yang ada di masyarakat Desa Pallis Kecamatan Balanipa Kabupaten Polewali Mandar yang dalam hal ini menjadi mitra program kegiatan KKN Mandiri seperti ketidaksiplinan dan tidak pahamnya masyarakat dalam penerapan protokol kesehatan, kebiasaan mencuci tangan dengan sabun, tidak memakai masker saat beraktifitas di luar rumah serta tidak terdapat spanduk dan sticker edukasi pencegahan Covid-19. Kondisi tersebut membawa kekhawatiran yang dapat menambah potensi penyebaran dan peningkatan jumlah kasus Covid-19 oleh karena itu Upaya Pencegahan Penularan Covid-19 melalui Program KKN Mandiri Dengan Tema Pencegahan Covid-19 oleh Dosen Pendamping Lapangan (Supervisor KKN) dan Mahasiswa Universitas Sulawesi Barat, kiranya dapat menjadi jawaban atas kondisi yang terjadi tersebut dalam bentuk pembuatan dan penyusunan programprogram KKN.

\section{METODE}

Kegiatan KKN Mandiri Gelombang XV Tahun 2020 ini dilaksanakan di salah satu Desa yang ada di Kabupaten Polewali Mandar yaitu Desa Pallis tepatnya berada dalam wilayah Kecamatan Balanipa yang berlangsung selama 40 Hari. Metode pelaksanaan dilakukan melalui beberapa tahap yaitu : 1.Melakukan Observasi di Lokasi KKN untuk menggali informasi terkait permasalahan di desa lokasi KKN. 2.Penyusunan Program Kerja KKN dibuat oleh Mahasiswa untuk kemudian dikonsultasikan dengan Dosen Pendamping Lapangan (Supervisor KKN) dan jika sekiranya Supervisor KKN menilai Program Kerja tersebut dapat menjadi solusi terkait masalah yang ada di masyarakat maka Dosen Pendamping Lapangan (Supervisor KKN) menyetujui Rancangan Program Kerja tersebut untuk dilaksanakan selama masa KKN. 3. Pelaksanaan Program Kerja KKN oleh Mahasiswa dengan tetap didampingi oleh Supervisor KKN dikarenakan Supervisor 
KKN memiliki wewenang menegakkan kedisiplinan mahasiswa dalam melaksanakan KKN Mandiri, mengarahkan dan mengendalikan kegiatan, perilaku, moralitas maupun etika mahasiswa serta memberikan Motivasi, mengarahkan dan membantu mahasiswa dalam memecahkan masalah yang ada. 4.Melakukan Monitoring dan Evaluasi sehingga Target dari Pelaksanaan Program KKN Mandiri dapat tercapai dan terlaksana dengan baik.

Adapun sasaran dari kegiatan KKN Mandiri ini adalah seluruh kelompok masyarakat yang ada di Desa Pallis. Dalam kegiatan ini, diharapkan akan terwujud masyarakat tanggap Covid-19 dan dapat meminimalisir penyebaran Virus Corona sesuai dengan Tema Kegiatan KKN Mandiri Universitas Sulawesi Barat kali ini yaitu "Upaya Pencegahan dan Penanggulangan Covid-19". Kegiatan Pengabdian Kepada Masyarakat yang dalam hal ini dilaksanakan dalam bentuk Program Kerja KKN Mandiri dilakukan dengan cara sosialisasi Door to Door atau mendatangi rumah-rumah warga dengan menggunakan metode ceramah sesuai dengan anjuran pemerinta karena metode ini dinilai sangat efektif mencegah terjadinya kerumunan warga bilamana dilaksanakan pada suatu Gedung / Aula Pertemuan (Ardiputra et al., 2020).

Selanjutnya ada beberapa materi atau bahan yang akan disampaikan kepada masyarakat dengan sosialisasi secara Door to Door antara lain : Pemberian pemahaman kepada masyarakat tentang penerapan PHBS dengan membiasakan mencuci tangan dengan sabun, memakai masker saat beraktifitas di luar rumah serta pemasangan spanduk dan sticker edukasi pencegahan Covid-19. Diakhir sosialisasi inipun dirangkaikan dengan pembagian Sabun cuci tangan cair yang merupakan salah satu hasil karya produk Mahasiswa KKN yang dibagikan kepada setiap rumah tangga / kelompok masyarakat sasaran.

\section{HASIL DAN PEMBAHASAN}

\section{Pemberian pemahaman kepada masyarakat tentang penerapan PHBS (CTPS).}

Pemerintah gencar menyusun rencana untuk menghadapi virus pandemi global ini. Penggunaan Sabun dan Desinfektan merupakan salah satu bentuk perlawanan dalam menghadapi Pandemi Covid-19. Mencuci tangan dengan sabun dapat mencegah penularan virus Covid-19 (Sinaga et al., 2020). Kandungan sabun terbukti secara klinis mampu membunuh bakteri, virus, dan kuman penyakit. Mencuci tangan dengan sabun adalah langkah dasar yang paling mudah dan aman untuk melindungi diri dari virus dan merupakan anjuran dari WHO. Corona Virus Disease 19 dapat berada di mana saja, bahkan menempel di benda-benda yang berada di sekitar kita sehingga CTPS dinilai sebagai cara yang efektif mencegah penularan virus tersebut. Membiasakan diri mencuci tangan dengan sabun dan air mengalir ini sangat penting dilakukan dan merupakan kunci untuk membunuh, merusak, dan mematikan virus yang mencemari tangan kita.

Menurut Depkes RI (2007), masyarakat harus mengetahui bagaimana mencuci tangan dengan air dan sabun dengan benar (Notoatmodjo, 2007). Menurut Peraturan Menteri Kesehatan RI No.3 Tahun 2014 bahwa mencuci tangan yang benar adalah salah satu unsur dari tiga pilar pembangunan Indonesia bidang kesehatan yakni berpola hidup sehat (K. K. RI, 2014). Pada saat makan, kuman dengan cepat masuk ke dalam tubuh, yang bisa menimbulkan penyakit. Sabun dapat membersihkan kotoran dan membunuh kuman, karena tanpa sabun kotoran dan kuman masih tertinggal di tangan. Mencuci tangan dapat membersihkan tangan dari kuman penyakit serta mencegah penularan penyakit seperti diare, typhus, disentri, kolera, penyakit kulit, kecacingan dan ISPA (Notoatmodjo, 2003).

Penyuluhan yang dilakukan, tetap mengikuti protokol kesehatan yang telah dianjurkan oleh Pemerintah. Para tim abdimas memberikan penyuluhan Perilaku Hidup Bersih dan Sehat (PHBS) kepada masyarakat tentang bagaimana cara mencuci tangan yang baik dan benar. Setelah memberikan contoh cara mencuci tangan yang baik dan benar, para masyarakat pun mengikuti instruksi secara perlahan, tahapantahapan cara mencuci tangan sesuai dengan anjuran WHO (World Health Organization). Untuk mengurangi resiko, pemerintah menganjurkan masyarakat menjaga kebersihan termasuk mencuci tangan dengan sabun sesering mungkin dan menutup mulut saat batuk atau bersin (Ardiputra et al., 2020). Perilaku hidup bersih dan sehat (PHBS) bisa dimulai sejak dini dengan cara sederhana yakni membiasakan diri mencuci tangan menggunakan sabun. "Tangan adalah anggota tubuh yang paling sering berhubungan langsung dengan mulut dan hidung, karena itu harus mulai untuk membiasakan cuci tangan agar kita terhindar dari kuman.

Sosialisasi ini dilaksanakan untuk memberikan alasan esensial dan menumbuhkan kesadaran agar mau dan mampu melakukan CTPS dan menyadarkan masyarakat bahwa CTPS menjadi kebutuhan didalam hidupnya dan keluarganya. Sosialisasi dalam bentuk ceramah tanpa disertai dengan edukasi, tentunya hanya akan membentuk ingatan sementara saja. Oleh karena itu pada kegiatan ini disertai dengan pemberian edukasi agar ingatan peserta dapat bertahan lama dengan melakukan praktek langsung 6 langkah CTPS disertai 8 gerakan (D. P. K. dan P. M. K. K. RI, 2020).

Setelah dilakukan sosialisasi dan penyuluhan kepada masyarakat sehingga masyarakat dapat mengetahui dan memahami mengenai pentingnya perilaku mencuci tangan dengan menggunakan sabun, cara yang benar mencuci tangan dan kapan saja diperlukan cuci tangan pakai sabun. Selanjutnya dilakukan kegiatan praktek cuci tangan menggunakan sabun dan air mengalir dimana peserta seluruh masyarakat melakukan CTPS sesuai arahan oleh tim pengabdi dengan menggunakan sabun dan air mengalir dengan praktek sendiri dan dengan gerakan yang benar. Sehingga dengan terlaksananya kegiatan ini maka seluruh 
masyarakat termotivasi menerapkan salah satu bentuk PHBS yaitu melakukan CTPS sebelum dan sesudah beraktifitas.

\section{Pentingnya penggunaan Masker saat beraktifitas diluar rumah.}

Penyebaran pada masyarakat pun dapat dikurangi salah satunya dengan menjaga kebersihan tangan secara rutin (Beiu et al., 2020) dan upaya penggunaan masker (Greenhalgh et al., 2020). Hal ini perlu dilakukan karena Covid-19 dapat dengan mudah ditularkan melalui jalur pernapasan (tetesan dari orang yang terinfeksi, melalui batuk atau bersin) dan melalui kontak dengan permukaan yang terkontaminasi. Seperti yang sudah dilakukan oleh masyarakat China, bahwa penggunaan masker sudah menjadi kewajiban yang harus diterapkan (Matthay et al., 2020).

Kegiatan ini dilakukan oleh karena untuk meningkatkan pemahaman mengenai upaya preventif masyarakat terhadap pandemi Covid-19 sekarang ini, yaitu dengan cara penggunaan masker. Masyarakat perlu mendapatkan pemaparan ilmu pengetahuan baik secara langsung maupun tidak langsung. Ilmu pengetahuan yang disampaikan adalah berupa edukasi secara lisan per orang dan tidak berkumpul oleh karena keterbatasan kami dalam proses penyampaian terkait anjuran pemerintah untuk tidak membuat kerumunan. Hasil pengabdian kepada masyarakat adalah terlaksanya sosialisasi dalam bentuk edukasi kepada masyarakat desa pallis terkait pentingnya penggunaan masker saat beraktifitas di luar rumah dan hal ini terlihat jelas akan kesadaran masyarakat sekitar setelah mendapatkan edukasi dari para tim abdimas.

\section{Pemasangan Spanduk dan Sticker Edukasi pencegahan Covid-19.}

Salah satu cara untuk memberikan pemahaman lebih mendalam ke masyarakat adalah dengan cara sosialisasi dan edukasi melalui perangkat media luar seperti poster, spanduk, sticker dan lain sebagainya. Dalam hal ini, selain memasang sticker disetiap rumah warga, kami juga melakukan pemasangan spanduk edukasi pada area-area yang sering menjadi titik kumpul masyarakat seperti Musallah, Masjid dan Kantor Desa yang juga merupakan fasilitas pelayanan publik masyarakat setempat yang juga dapat menjadi titik kumpul.

\section{SIMPULAN}

KKN Mandiri merupakan salah satu bentuk pengabdian kepada masyarakat yang dinisiasi oleh Pusat Pengembangan Kuliah Kerja Nyata (P2KKN) Universitas Sulawesi Barat dengan Tema "Upaya Pencegahan Dan Penanggulangan Covid-19". Dan berdasarkan hasil observasi lapangan ditemukan berbagai masalah yang ada di masyarakat Desa Pallis Kecamatan Balanipa Kabupaten Polewali Mandar yang dalam hal ini menjadi mitra program kegiatan KKN Mandiri seperti ketidaksiplinan dan tidak pahamnya masyarakat dalam penerapan protokol kesehatan, kebiasaan mencuci tangan dengan sabun, tidak memakai masker saat beraktifitas di luar rumah serta tidak terdapat spanduk dan sticker edukasi pencegahan Covid-19. Kondisi tersebut membawa kekhawatiran yang dapat menambah potensi penyebaran dan peningkatan jumlah kasus Covid-19. Sehingga kami selaku tim abdimas melakukan upaya pencegahan penularan Covid-19 melalui program kerja KKN Mandiri yang sebelumnya telah disusun terlebih dahulu dalam rangka menjawab tantangan terkait permasalahan yang ada di masyarakat.

Berikut adalah beberapa dari sekian banyak program kerja yang kami buat dan jalankan seperti Pemberian pemahaman kepada masyarakat tentang penerapan PHBS dengan membiasakan mencuci tangan dengan sabun, memakai masker saat beraktifitas di luar rumah serta pemasangan spanduk dan sticker edukasi pencegahan Covid-19. Beberapa program diatas telah terlaksana dengan baik sesuai dengan schedule yang terdapat pada program kerja dan mendapat antusiasme serta respon positif dari masyarakat setempat.

\section{UCAPAN TERIMA KASIH}

Terima Kasih didampaikan kepada Pusat Pengembangan Kuliah Kerja Nyata (P2KKN) Universitas Sulawesi Barat yang telah memfasilitasi kegiatan Kuliah Kerja Nyata (KKN) dan juga kepada Pemerintah Desa Pallis berserta masyarakat yang telah bersedia menjadi mitra dalam kegiatan Kuliah Kerja Nyata (KKN) sekaligus Pengabdian Kepada Masyarakat (PKM).

\section{DAFTAR PUSTAKA}

(2020a), K. K. R. (n.d.). Pedoman Pencegahan dan Pengendalian Coronavirus Disease (COVID-19)'. Kemenkes RI, 0-115.

Ardiputra, S., Prawira, M. R., M.Tasbir, Permata, S. U., Listiawati, N., \& Qadrini, L. (2020). Pembagian Masker Dan Sosialisasi Kebijakan Pemerintah Dalam Rangka Mendukung Pencegahan Penyebaran Covid-19 Pada Masyarakat Desa Pallis Kecamatan Balanipa. Community Development Journal : Jurnal Pengabdian Masyarakat, 1 No.3, 395-400. https://doi.org/https://doi.org/10.31004/cdj.v1i3.1095

Beiu, C., Mihai, M., Popa, L., Cima, L., \& Popescu, M. N. (2020). Frequent hand washing for COVID-19 
prevention can cause hand dermatitis: management tips. Cureus, 12(4).

Gan, W. H., Lim, J. W., \& Koh, D. (2020). Preventing intra-hospital infection and transmission of coronavirus disease 2019 in health-care workers. Safety and Health at Work, 11(2), 241-243.

Greenhalgh, T., Schmid, M. B., Czypionka, T., Bassler, D., \& Gruer, L. (2020). Face masks for the public during the covid-19 crisis. Bmj, 369.

Matthay, M. A., Aldrich, J. M., \& Gotts, J. E. (2020). Treatment for severe acute respiratory distress syndrome from COVID-19. The Lancet Respiratory Medicine, 8(5), 433-434.

Musafira, F., Qadrini, L., Fatimah, M. F., \& Ardiputra, S. (2020). Edukasi Pembuatan Dan Penyemprotan Desinfektan Pada Masyarakat Di Desa Suruang Kecamatan Campalagian Kabupaten Polewali Mandar. Community Development Journal: Jurnal Pengabdian Masyarakat, 1(3), 416-421. https://journal.universitaspahlawan.ac.id/index.php/cdj/article/view/1110

Nathavitharana, R. R., Patel, P. K., Tierney, D. B., Mehrotra, P., Lederer, P. A., Davis, S., \& Nardell, E. (2020). Innovation and knowledge sharing can transform COVID-19 infection prevention response. $J$ Hosp Med, 15(5), 299-301.

Notoatmodjo, S. (2003). Prinsip-prinsip dasar ilmu kesehatan masyarakat. Jakarta: Rineka Cipta, 10.

Notoatmodjo, S. (2007). Promosi kesehatan dan ilmu perilaku. Jakarta: Rineka Cipta, 20.

RI, D. P. K. dan P. M. K. K. (2020). Direktorat Promosi Kesehatan dan Pemberdayaan Masyarakat Kementerian Kesehatan RI - 6 Langkah Cuci Tangan Pakai Sabun. Direktorat Promosi Kesehatan Dan Pemberdayaan Masyarakat Kementerian Kesehatan RI. https://promkes.kemkes.go.id/6-langkah-cucitangan-pakai-sabun

RI, K. (2020). Pedoman Pencegahan dan Pengendalian Coronavirus Disease (COVID-19)'. Kemenkes RI, O115.

RI, K. K. (2014). Peraturan Menteri Kesehatan RI No.3 Tahun 2014.

Sinaga, L. R. V., Munthe, S. A., \& Bangun, H. A. (2020). Sosialisasi perilaku cuci tangan pakai sabun di desa sawo sebagai-bentuk kepedulian terhadap masyarakat ditengah mewabahnya virus covid-19. Jurnal Abdimas Mutiara, 1(2), 19-28.

Voss, A., Coombs, G., Unal, S., Saginur, R., \& Hsueh, P.-R. (2020). Publishing in face of the COVID-19 pandemic. International Journal of Antimicrobial Agents, 56(1), Art-106081.

Wu, Y.-C., Chen, C.-S., \& Chan, Y.-J. (2020). The outbreak of COVID-19: an overview. Journal of the Chinese Medical Association, 83(3), 217. 